\title{
Trade of marine turtles along the Southwestern Coast of the Gulf of Venezuela
}

\author{
H. Barrios-Garrido 1,2,3* N. Espinoza-Rodríguez², D. Rojas-Cañizales ${ }^{2,3}$, J. Palmar², N. Wildermann 1,2,3, \\ M. G. Montiel-Villalobos ${ }^{2,4}$ and M. Hamann ${ }^{1}$
}

\begin{abstract}
Background: Marine turtles play an important role in the culture and economy of numerous coastal communities around the world. However, the legal framework that regulates the consumptive use of these reptiles varies among countries.For example, the consumption of these reptiles has been regarded as common in several rural areas of Venezuela, especially in the eastern coast of the Guajira Peninsula.

Methods: To assess the scale and cultural component of this use, we interviewed 35 residents from the southwestern coast of the Gulf of Venezuela (Venezuelan part of the Guajira Peninsula), using a combination of in-depth and semistructured interviews. We carried out a field and detailed market-based observations on the Guajira Peninsula to detect the sale and use of marine turtle products. We focused on three main categories of use; the type of product, routes of trade, and the price of products.

Results: All of the marine turtle species reported from the Gulf of Venezuela were used, and the prices of products varied among their type, species of origin, and the distance from the capture area to a marketplace. We obtained evidence connecting Wayuú Indigenous people's traditions and beliefs with marine turtle use, and also they are used as traditional products such as medicine, and as an economic resource to sustain their communities.

Conclusion: It is probable that trade of marine turtle products is placing pressure on populations in the Gulf of Venezuela. We recommend the implementation of an inter-institutional conservation-portfolio be developed for the Peninsula to evaluate actions related to this concern.
\end{abstract}

Keywords: Illegal trade, Marine turtles, Gulf of Venezuela, Colombia, Wayuú people

\section{Background}

Marine turtles are exposed to multiple, and cumulative threats throughout their lives, and the extent to which species are exposed differ (Wallace et al. 2011). One welldocumented threat is the capture for the intent of consumption, either as a result of incidental bycatch or intentional take. Consumptive use of marine turtles, especially illegal retention and use of these species is often linked to artisanal fisheries occurring in developing tropical countries (Buitrago

\footnotetext{
* Correspondence: hector.barriosgarrido@my.jcu.edu.au

'TropWATER - Centre for Tropical Water and Aquatic Ecosystem Research;

College of Marine and Environmental Sciences, James Cook University,

Townsville, Australia

${ }^{2}$ Grupo de Trabajo en Tortugas Marinas del Golfo de Venezuela (GTTM-GV), Maracaibo, Venezuela

Full list of author information is available at the end of the article
}

et al. 2008). However, in-depth investigations on this topic tend to be complicated due to the often clandestine nature of turtle fisheries (Mancini and Koch 2009). In general, the data on this human-turtle interaction is lacking in the literature (Hamann et al. 2010; Rees et al. 2016).

For thousands of years marine turtles have played an important role in many cultures around the world (Antczak et al. 2007; Frazier 2005; Olijdam 2001). Yet over the past few hundred years many populations have been exposed to some degree of systematic commercial use (Lagueux et al. 2014; Nada and Casale 2011). The scale, and impact of commercial use varied considerably and some populations were exposed to pervasive pressure that lasted many decades and caused declines in population sizes. 
In recent decades marine turtles have been afforded stronger conservation and protection at international (e.g. CITES) and national (e.g. legislation to regulate use) scales (Roberts and Hamann 2016). The rise in the number of conservation and policy instruments protecting turtles has essentially meant that there are now fewer commercial markets (Humber et al. 2014). However, marine turtles are still subject to use in some places of the world. For example they are used legally by some Indigenous cultures for traditional rites, culture and trade (Fleming 2001; Frazier 2009). For instance, in Australia, Aboriginal and Torres Strait Islander People maintain legal, noncommercial traditional use under Australia's Native Title Act (1993), which links non-commercial use to Traditional cultural protocols (Butler et al. 2012; Weiss et al. 2013). Similarly, in the American continent, the use and trade of marine turtle products occurs along much of the tropical coastline (Bräutigam and Eckert 2006; Rueda-Almonacid et al. 1992); and some Indigenous peoples from the Caribbean continue to use marine turtles as a totem, a form of currency and as a spiritual link between humans and the divine world (Ankersen et al. 2015; Barrios-Garrido and Montiel-Villalobos 2006; Roe Hulse 2005). In the majority of countries in the Caribbean the consumptive use of marine turtles as classed as illegal by national Government legislation (Humber et al. 2014). For example, Venezuela, which, as a signatory state of several international treaties that protect marine turtles, has developed national laws and presidential decrees to protect marine turtles from consumptive use (Venezuela 2009; Venezuela 1996a, 1996b, 1996c).

Understanding how, where, when and why consumptive use may be occurring is crucial for the development or enforcement of policies or legislation that offer protection to marine turtles and/or their habitats. Further, the development of management strategies or the enforcement of legislation is especially challenging when the protective status of the species or the legislation regarding threats such as consumption are not clear (Richardson et al. 2006; Stringell et al. 2013). For example, in the Caribbean waters of Nicaragua the consumptive use of marine turtle is considered legal but it is regulated by conditions dealing with ethnicity, turtle size, and species. Yet in reality, fishers do not always follow these rules when landing catches of marine turtles in the artisanal ports of this region (Lagueux et al. 2014). As a result, the boundary between illegal and legal tends to be clouded.

Despite the legal framework protecting marine turtles in Venezuela, the use and trade of marine turtle products in the country is common, predominantly by people living in remote coastal areas (Guada and Sole 2000; Montiel-Villalobos 2012; Rojas-Cañizales 2015; Vernet and Gómez 2007). Here, in these coastal areas, especially in the Venezuelan Guajira Peninsula, and despite the legal protection of marine turtles in Venezuela, the
Peninsula's Wayuú Indigenous inhabitants acknowledge that they continue to use marine turtles as a cultural tradition and to improve their livelihoods (Barrios-Garrido and Montiel-Villalobos 2010, 2016). However, the policy and legal situation is complex. Although the Wayuú people's use of turtles would be classed as illegal under wildlife protection legislation, Venezuela also has national legislation aimed at protecting the rights of Indigenous peoples and their tribal communities. This legislation states that the Venezuelan Indigenous people have rights to use the regions natural resources, especially resources occurring within the ancestral territories (Venezuela 2005). In addition, there is an International treaty signed and ratified by the Venezuela Government to protect the traditional use of natural resources within Venezuela (Indigenous and Tribal Peoples Convention) (ILO 1989). Thus it could be perceived that there is a conflict of legislation and/or policy, and progressing conservation initiatives for marine turtles in Venezuela and the southern Caribbean requires alignment of conservation and traditional goals of the Indigenous people and the local Government.

The Wayuú people ("Guajiros" in their language: "our people") comprise the largest demographic sector of Indigenous people in Venezuela (Cerquera Gonzalez 2008). Based on their narratives during the Spanish conquer (mid 1700's), they were classified into two main groups: shepherds and fishermen (this latter also known as Apaalanchi in Wayuúnaikii) (Martínez 2011). Apaalanchis reside along the coast and depend on coastal resources for their livelihoods. As a result, artisanal fishing is the most common economic activity in the region, and it is well established in the La Guajira Peninsula (especially in the Venezuelan part of it). Apaalanchi (Wayuú) elders, clan leaders and fishers have described themselves as "shepherds of the sea", and marine turtles as an animal used to sustain their culture; "marine turtles are for our people like oil is to Venezuela" (Interview: Fernández J., In: Soré et al. 2006). Previous authors have also reported the consumptive use of marine turtles (and their secondary products) by the Wayuú people (Martínez 2011; Parra 2002); however the details on how this use occurs were not provided, as well as the strong relationship between Wayuú culture.

Wayuú cultural laws are passed orally across generations and are well respected by people in their everyday life (Balza-García 2010; Macías and Garzón 2005; Paz Reverol et al. 2010; Riaño-Alcalá 2014). However, transcultural aspects have modified the needs of Venezuelan Indigenous communities, leading to the inclusion of a commercial component into their local economy and livelihood (Castellano-Gil and Barrios-Garrido 2006; Robles 2008). Now, Wayuú people use a variety of different marine turtle body parts as commercial items: for example meat (mainly pectoral muscles), carapace, as 
well as the scutes of hawksbill turtles. This shift towards commercial use of marine turtles has placed increased pressure on the Gulf of Venezuela's marine turtles and its management is important because regional marine turtle populations are considered to be conservation dependent in Venezuela (Barrios-Garrido et al. 2015; Buitrago et al. 2015a; Buitrago et al. 2015b; Guada et al. 2015; Rondón-Médicci et al. 2015). Hence, pervasive commercial use, or use not managed by communitybased programs could compromise the status of marine turtle species within Venezuelan waters (Barrios-Garrido and Montiel-Villalobos 2010).

Green turtles have been reported as the species most impacted by commercial consumptive use in the Gulf of Venezuela (Guada and Sole 2000; Rojas-Cañizales 2015). In 1987 and 1989, trade and consumptive use of marine turtles in the area was reported but classified as low in magnitude (Acuña et al. 1989; Sideregts et al. 1987). However, recent studies carried out in the Venezuelan region have quantified the take to be around $3649 \pm 434$ green turtles per year (Montiel-Villalobos 2012). This number, plus the 5000 to 6000 green turtles captured annually and reported by Rueda-Almonacid et al. (1992) from the Colombian portion of the Guajira Peninsula places to the Guajira Peninsula as the second most important turtle fishery in the Caribbean after the fishery in Miskitos (Nicaragua) (Lagueux et al. 2014). It is important to recognise that these numbers were calculated only for green turtles captured and did not include annual estimations for any other species of turtle.

The majority of green turtles taken annually between the Colombian and Venezuelan areas of the Guajira Peninsula are generally used for traditional consumption, or are traded commercially (Rojas-Cañizales 2015; Villate 2010). Indeed, some authors have shown there is also a high demand of marine turtle products among Wayuú people who reside in Colombian area of the Peninsula (Borrero Avellaneda et al. 2013; Rueda-Almonacid et al. 1992; Villate 2010). However, while use appears to be widespread throughout the coastal areas of the Gulf of Venezuela the differentiation between the traditional use and illegal trade remains a challenge to understand and regulate. The aim of this paper is to assess the scale and magnitude and cultural component of this use on the southwestern coast of the Gulf of Venezuela (Venezuelan portion of the Guajira Peninsula), including some references to the legislation conflict among the national laws (environmental, cultural and social) and international treaties.

\section{Methods}

\section{Study area}

The study was conducted in locations believed to be the principal trading centres of marine turtles (a) Guajira:
Castilletes, Porshoure, Kazuzain, Neima, Paraguaipoa; (b) Mara: San Rafael del Moján; (c) Maracaibo: north-western Maracaibo (Bomba Caribe, La Tubería, Motocross, and Maicaito neighbourhoods). Trading centres were identified during preliminary surveys conducted by HBG and MGMV in the Guajira, Mara and Maracaibo municipalities, using personal observation and informal interviews with fishers (Table 1).

The selected ports and public markets were located along the southwestern coast of the Gulf of Venezuela (GV), from Castilletes (11.8483 N; 71.3240 W) to Zapara Island (10.9549 N; 71.5290 W) (Fig. 1). In each locality the surrounding populated areas often lacked basic amenities, such as access to clean water supply, sewage service, and house-hold electricity (although in Paraguaipoa, San Rafael del Moján, and Maracaibo electricity is considered more reliable).

The GV is located in the upper and exterior slump of the Maracaibo Lake System (Barrios-Garrido et al. 2016; Medina and Barboza 2003; Morán et al. 2014), and this coastal region represents one of the most important feeding grounds for marine turtles in Venezuela (BarriosGarrido et al. 2015; Buitrago et al. 2015a; Buitrago et al. 2015b; Guada et al. 2015; Rondón-Médicci et al. 2015). Studies within the last decade have confirmed the presence of five marine turtle species in GV region of Venezuela (Barrios-Garrido 2003; Montiel-Villalobos 2012; Parra 2002); Chelonia mydas (green turtle), Eretmochelys imbricata (hawksbill turtle), Caretta caretta (loggerhead turtle), Dermochelys coriacea (leatherback turtle) and Lepidochelys olivacea (olive ridley turtle).

\section{Data collection}

Data were collected between January 2002 and January 2017 (Table 1). Our data included semi-structured in-depth interviews (open-ended), preliminary observations and informal interviews, plus our own systematic observations in the markets and trading centres of Venezuelan portion of the Guajira Peninsula. The interviewees (key-informants) were fishers, transporters, wholesalers, business holders (restaurant and non-restaurant owners, and artisans), and buyers.

We categorised respondents according to the main activity they conducted out in the last 5 years: (a) fisher/ fish collector is either specialised as a turtle hunter (owner of "turtle nets" - nets with more than $20 \mathrm{~cm}$ mesh size) or not specialised (opportunistic turtle catcher). Further, a fish collector is a person who owns a refrigeration system and could store butchered marine products (turtle, spiny lobster, and fishes) for periods of more than 1 week; (b) wholesaler or transporter; these are people who purchase turtles from the fishers and are then responsible for making secondary transactions, on-selling the products (wholesaler), or a person who has the 
Table 1 Data collection methods for marine turtle trade evaluation in the Gulf of Venezuela (2002 - 2017)

\begin{tabular}{|c|c|c|c|}
\hline Timeline & Method & Personnel involved & Places evaluated \\
\hline \multirow[t]{2}{*}{ January 2002 - July 2003} & Informal interviews & \multirow{2}{*}{$\begin{array}{l}\text { Biologists with expertise on marine } \\
\text { turtles (HBG, MGMV) and trained } \\
\text { community members (JP) }\end{array}$} & $\begin{array}{l}\text { Eight trade centres } \\
\text { (artisanal fishing port areas) }\end{array}$ \\
\hline & Market-based observation & & $\begin{array}{l}\text { Four markets } \\
\text { (populated centres) }\end{array}$ \\
\hline July 2005 - August 2008 & $\begin{array}{l}\text { Semi-structured in-depth } \\
\text { interviews (Appendix) }\end{array}$ & $\begin{array}{l}\text { Biologists with expertise on marine } \\
\text { turtles (HBG, NER, MGMV) and trained } \\
\text { community members (JP) }\end{array}$ & $\begin{array}{l}\text { Six trade centres (artisanal } \\
\text { fishing port areas) }\end{array}$ \\
\hline \multirow[t]{2}{*}{ September 2008 - May 2011} & \multirow[t]{2}{*}{ Market-based observation } & \multirow[t]{2}{*}{$\begin{array}{l}\text { Biologists with expertise on marine } \\
\text { turtles (HBG, NER, NW) }\end{array}$} & $\begin{array}{l}\text { Eight trade centres } \\
\text { (artisanal fishing port areas) }\end{array}$ \\
\hline & & & $\begin{array}{l}\text { Three markets } \\
\text { (populated centres) }\end{array}$ \\
\hline \multirow[t]{2}{*}{ November 2012 - November 2013} & \multirow[t]{2}{*}{$\begin{array}{l}\text { Semi-structured in-depth } \\
\text { interviews (Appendix) }\end{array}$} & \multirow{2}{*}{$\begin{array}{l}\text { Biologists with expertise on marine } \\
\text { turtles (DRC, NER) and trained } \\
\text { community members (JP) }\end{array}$} & $\begin{array}{l}\text { Two markets } \\
\text { (populated centres) }\end{array}$ \\
\hline & & & $\begin{array}{l}\text { Two trade centres } \\
\text { (artisanal fishing port areas) }\end{array}$ \\
\hline \multirow[t]{2}{*}{ August 2014} & \multirow[t]{2}{*}{ Market-based observation } & \multirow[t]{2}{*}{$\begin{array}{l}\text { Biologists with expertise on marine } \\
\text { turtles (HBG, DRC) }\end{array}$} & $\begin{array}{l}\text { Eight trade centres } \\
\text { (artisanal fishing port areas) }\end{array}$ \\
\hline & & & $\begin{array}{l}\text { Four markets } \\
\text { (populated centres) }\end{array}$ \\
\hline \multirow[t]{2}{*}{ January 2015 - January 2017} & \multirow[t]{2}{*}{ Personal observations } & \multirow[t]{2}{*}{ Trained community members (JP) } & $\begin{array}{l}\text { Four trade centres } \\
\text { (artisanal fishing port areas) }\end{array}$ \\
\hline & & & $\begin{array}{l}\text { Four markets } \\
\text { (populated centres) }\end{array}$ \\
\hline
\end{tabular}

financial capacity to not only buy the products, but transport them to another market or location (transporter), usually they have access to a $4 \times 4$ vehicle with an ice container to keep the products fresh (called "Turtle trucks" in Spanish "Camion Tortuguero"); (c) business owners or final sellers, generally they purchase from the wholesalers or transporters and some of them have the means to keep the animals alive until their final use; (d) final buyers, person who buy the final product (e.g. turtle dish, hawksbill scutes, or other turtle products).

All in-depth interviews were conducted by HBG, NER, DRC, NW, MGMV, and JP in collaboration with Opportune Information Network protocol (in Spanish, Red de Aviso Oportuno - RAO-Zulia) (Barrios-Garrido and Montiel-Villalobos 2016; Vernet and Gómez 2007). We located people to interview using the "snowballing" technique, in which the recommendation of the each interviewee is used to locate additional potential interviewees (according to their perceived experience with the interview topic). The in-depth interviews, using open-ended questionnaire (Appendix), were carried out by the authors in either Spanish or Wayuúnaikii (Wayuú Indigenous language) (JP is Wayuú clan leader, and the Wayuúnaikii is his first language). All the in-depth interviews were conducted in private locations, within the localities listed in Fig. 1. The interviewees were also asked about their general knowledge of marine turtle's species, presence and abundance in the area, and how they got that information.
To analyse the qualitative data we extracted common themes about: trade, traditional use, and anecdotic information related to marine turtles. We then counted the number of respondents who discussed each theme and the value they attributed to each of them (cultural, economic, livelihood, utilitarian, mythical, and medicinal) (Table 2). Some interviewees' responses were classified into more than one theme and/or value (See Table 2) (D'Lima et al. 2014).

We focussed on collecting data under three main themes: (a) trade (relates to the movement of the product such as capture and market locations, trade routes, and price of marine turtle products); (b) traditional use (non-commercial exchange of marine turtle products between families and clans); (c) anecdotic information about marine turtles (Tambiah 1999) (Appendix). When it was possible in the markets and trade centres, we photographed the turtles and products on sale after seeking the oral permission from the people involved (Figs. 2, 3, 4, 5 and 6). We defined trade (or commercial use) as the exchange of marine turtle products and secondary-products for money; this action involves a seller, sometimes a dealer or transporter, and a buyer. We included Colombian localities (Maicao and Riohacha) in the Fig. 1 due to the common reference to them made by the interviewees of these locations.

We conducted visual observations in eight trade centres, and four markets (Table 1). On those places we collected the information regarding prices. We, the non-Indigenous 


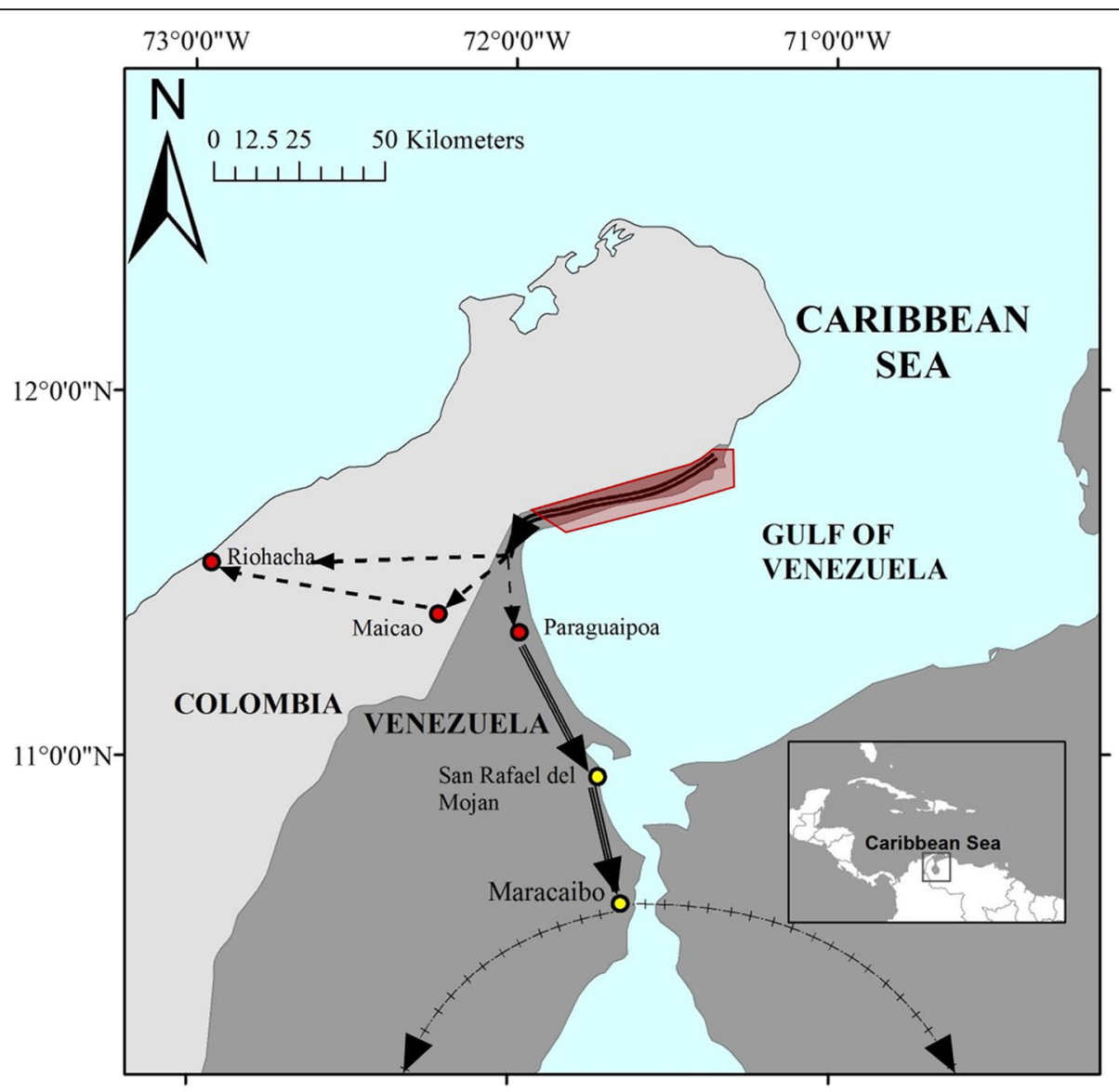

Fig. 1 Geographical location of the study area and the relative position of the study area in the Caribbean Sea (insert). Red polygon represents the areas where we found the marine turtle products. Double line arrow represents the direction of trade by wholesalers or transporters towards secondary sellers or business holders, the latter are represent by red dots (in Colombia: Maicao and Riohacha, and in Venezuela: Paraguaipoa). Dashed arrows represent the general route used by secondary sellers or transporters. Triple line arrows represent general routes used by transporters or secondary buyer towards main populated centres (as San Rafael del Moján and Maracaibo - yellow dots). Crossed arrows represent the general routes used to send the products into San Cristobal, Merida, and Lara states (in Venezuela)

authors (HBG, NER, DRC, NW, and MGMV), approached these places as potential buyers, then we contrasted the prices received for JP (Indigenous member of the community). Prices were calculated by 1 US dollar per 199 Venezuelan Bolivars (official Venezuelan rate in 2014, called SIMADI).

\section{Results}

We interviewed 35 people (26 between July 2005 and August 2008, and nine between November 2012 and November 2013). Seventeen of them were categorised as fishers and could be turtle-hunters or casual turtle catchers, only seven of 17 fishers had the capacity to store products (refrigerator system). Nine of the 35 were classed as wholesaler or transporter. Five were classed as business owners or secondary sellers, and four were classed as final buyers of the product. All 35 provided data regarding the use of marine turtle that occurs in the area. Our respondents were aged between 21 and 78 years old. We obtained a $100 \%$ of response rate.

During our surveys, we visited 12 populated centres (between cities and towns) and eight markets (Table 1), and observed how the turtle products in some cases were exhibited, and in other cases the turtle products are hidden from the general public and only shown after some gentle persuasion of the sellers. We also confirmed the variation in the prices in relation to the ethnicity of the buyers (difference in the prices provided to JP and the rest of the team members).

In particular, responses to our surveys, combined with our observations in markets, revealed that Wayuú people use marine turtles as a food, economic and cultural resource at locations spread along the southwestern coast of the Gulf of Venezuela (Table 2; Fig. 3). Also, among the potential marine turtle products we found were products with commercial value such as meat and guts from green and hawksbill turtles (Fig. 4), carapaces, hawksbill turtle 
Table 2 Common themes extracted from interviewees' answers, number of respondents, values attributed to each theme, and illustrated examples

\begin{tabular}{|c|c|c|}
\hline Theme (No. of respondents) & Value type & Illustrated example \\
\hline \multirow{4}{*}{$\begin{array}{l}\text { Marine turtles are key animals for Wayuú } \\
\text { people }(n=35)\end{array}$} & \multirow[t]{4}{*}{ Utilitarian } & "I raised my family thanks to the marine turtles" \\
\hline & & "if you put a turtle skull in a corral gate, the goats will have more offspring" \\
\hline & & "if turtles are around in the water the fish catching will be great" \\
\hline & & "My grandmother used the carapace as a container for food or clothes" \\
\hline \multirow[t]{3}{*}{$\begin{array}{l}\text { Wayuú fisher's economy is based in marine } \\
\text { turtles }(n=32)\end{array}$} & \multirow[t]{3}{*}{ Economic } & $\begin{array}{l}\text { "...nowadays my grandsons are attending the primary school because I } \\
\text { sell turtle meat to buy their books, uniforms, and everything" }\end{array}$ \\
\hline & & "Alijünas in Colombia pay really well the turtle products" \\
\hline & & $\begin{array}{l}\text { "We know that is considered illegal, but we need to use the turtles } \\
\text { to buy goods" }\end{array}$ \\
\hline \multirow{3}{*}{$\begin{array}{l}\text { Marine turtles are used as exchange trade } \\
\text { products }(n=21)\end{array}$} & \multirow[t]{3}{*}{ Livelihood } & "I prepare turtle oil for my brother, and he gives me goat's meat" \\
\hline & & $\begin{array}{l}\text { "In my family, we eat turtle at least once a month. If we do not eat it, } \\
\text { we will feel bad" }\end{array}$ \\
\hline & & $\begin{array}{l}\text { "During my childhood, my father had a corral for hens, and one corral } \\
\text { for turtles" }\end{array}$ \\
\hline \multirow[t]{3}{*}{ Marine turtles are divine creatures $(n=20)$} & \multirow[t]{2}{*}{ Mythical } & $\begin{array}{l}\text { "Marine turtles are gift from Maleiwa, but the Alijünas do not } \\
\text { understand that" }\end{array}$ \\
\hline & & $\begin{array}{l}\text { "in the ancient cemeteries, I found mixed human and marine } \\
\text { turtle bones" }\end{array}$ \\
\hline & Medicinal/Mythical & "Marine turtles saved my life" \\
\hline \multirow{2}{*}{$\begin{array}{l}\text { Marine turtles are the cultural core of Wayuú } \\
\text { fishers }(n=12)\end{array}$} & \multirow[t]{2}{*}{ Cultural/Mythical } & "My boy turned into a man when he sacrificed his first turtle" \\
\hline & & $\begin{array}{l}\text { "After the first period, the girls take a shower with 'moon water,' and its } \\
\text { container is a turtle carapace" }\end{array}$ \\
\hline
\end{tabular}

scutes (Fig. 5), leatherback turtle oil which is used as medicine according with Wayuús beliefs and traditions (Fig. 6), and some less common products (such as dried organs), or a prepared full meal (often turtle meat with white rice and soup) (Fig. 3).

We found that at least four of the five species of marine turtles that inhabit the Gulf of Venezuela are used commercially by local communities (Chelonia mydas, Eretmochelys imbricata, Caretta caretta, Dermochelys

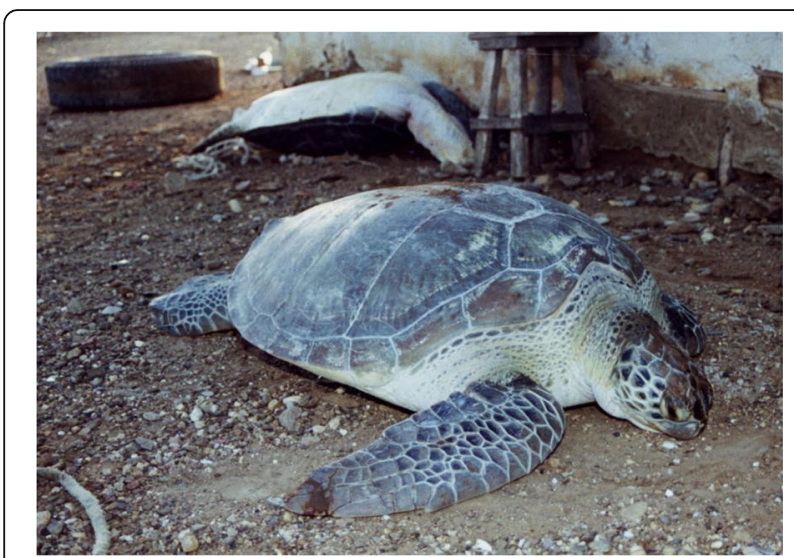

Fig. 2 Green turtles (Chelonia mydas) in the market place (Los Filúos) awaiting the final buyer(s). Photography: H. Barrios-Garrido coriacea) (Table 3; Fig. 2). We received no information about the use of Lepidochelys olivacea.

Our data from market observations plus responses from interviewees affirm that the green turtle is the most common species involved in the trade. The most common products generated from green turtles are the meat and guts, which are sold in public markets, restaurants, and are sometimes transported out of the Zulia state limits (towards other Venezuelan states, or into Colombian towns). The asking prices for green turtles varied according to the size of the animal. In the case of hawksbill turtles, some interviewees $(n=8)$ believe that the species is the "male" of the green turtle, and they are scarcer nowadays in the GV in comparison with historical recolection. Although meat from hawksbill turtles was also found in markets, the most profitable products extracted from this species are the carapace and its scutes. While we did observe loggerhead turtle products in the markets, it was not common, probably because when it is available it is more commonly shared between families. Indeed, our respondents affirm that its taste is too fishy to be attractive to buyers. Leatherback turtle's meat is not often consumed, rather its oil is the most popular item and it is generally used as medicine to cure or prevent asthma. According to five of our interviewees leatherback turtle oil is often requested by non-Indigenous people as well (called “Alijünas" in Wayuúnaikii). 


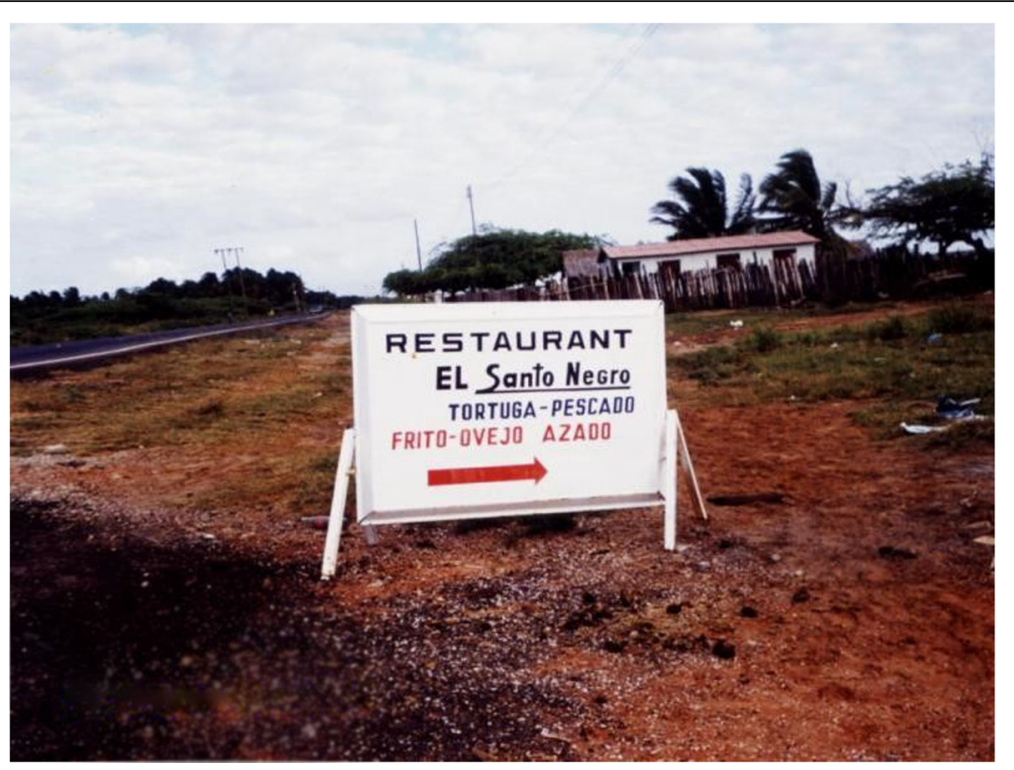

Fig. 3 Advertisement for turtle ("Tortuga") dishes. Advertisement placed next to the main route of the study area ("Troncal del Caribe"), next to the entrance to Caimare Chico beach, the most popular tourism destination in the Guajira municipality. Photography: H. Barrios-Garrido

The price of marine turtle products varied among species and product size/type. Prices typically range from US\$5 (e.g. for one kilogram of green turtle meat) to US\$300 for a whole adult-sized animal (green or hawksbill turtle) (Table 3). Our respondents affirmed

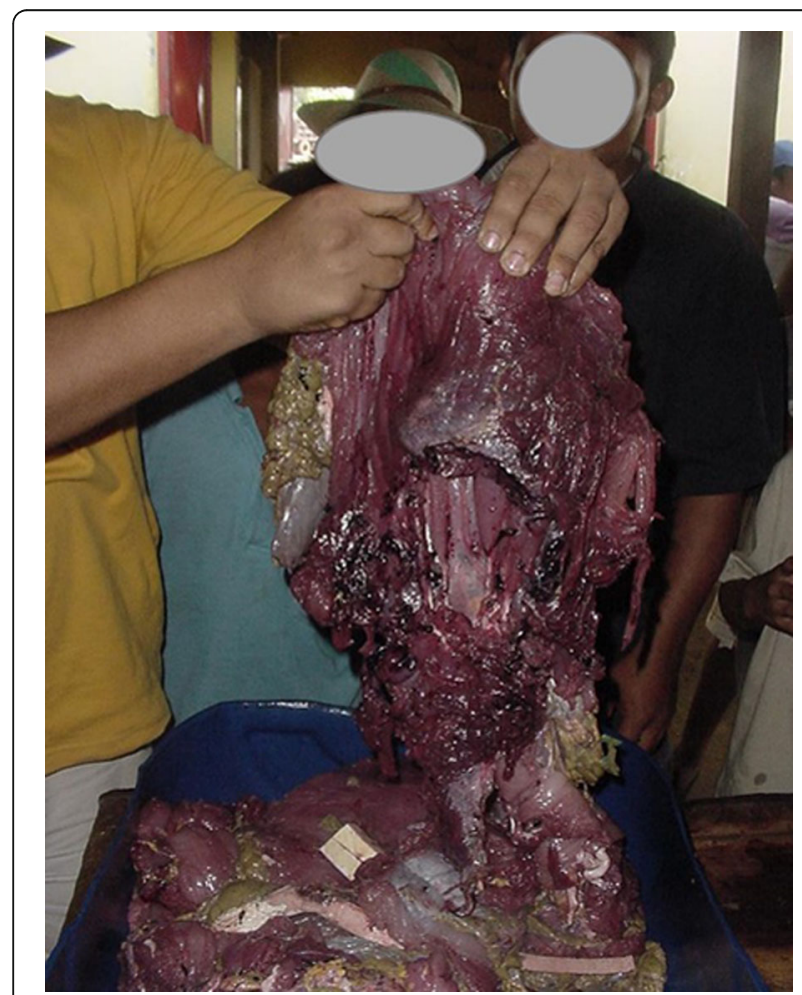

Fig. 4 Green turtle meat, guts and fat for sale in "Los Filúos" market, Paraguaipoa, Zulia state. Photography: H. Barrios-Garrido that this variation in price also fluctuates in relation to the difficulty associated with accessing animals (season, presence of army patrols, and frequency of the species). For example, hawksbill products tend to be more expensive due to their scarcity, and the relationship with this species and the traditional beliefs of the Wayuu people. We typically found lower prices in remote localities (for example from Castilletes to Neima) where most buyers were Indigenous and likely had lower incomes. This is in contrast to the higher prices (sometimes up to five times) that we found in localities where mestizos (non-Indigenous) customers were reported to purchase products (for example from Paraguaipoa to Maracaibo).

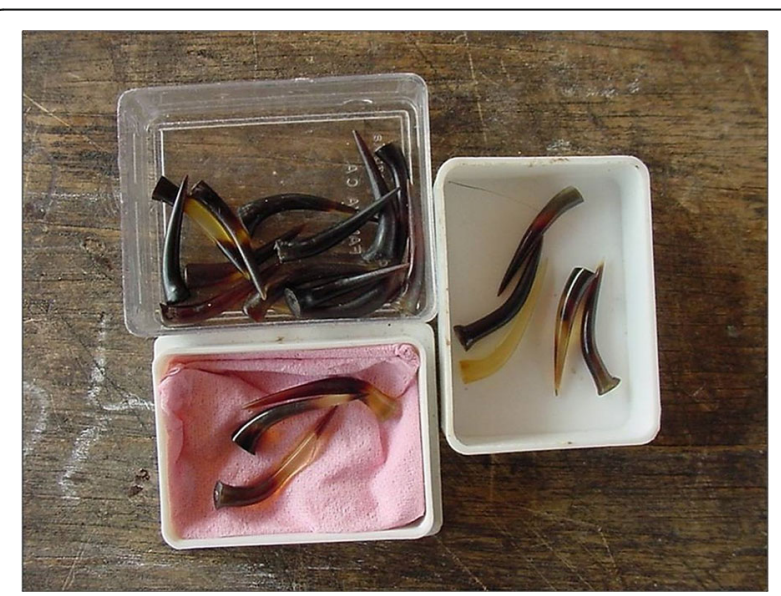

Fig. 5 Roosters spurs made from hawksbill turtle (Eretmochelys imbricata) scutes. Photography: H. Barrios-Garrido 


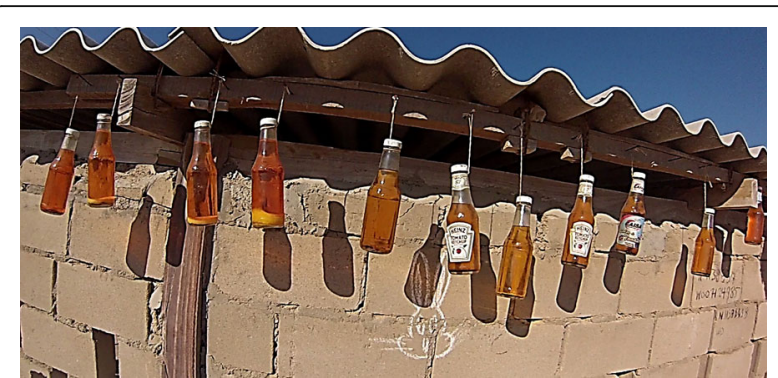

Fig. 6 Leatherback turtle (Dermochelys coriacea) oil bottled to be sold or exchanged between families. Photography: H. Barrios-Garrido

We found that juvenile and adult turtles were used commercially, were sold both dead and alive, and the prices varied according to the size of the turtles. We also found that the prices varied among years, localities, product, and trade centre. Close to one third of our respondents $(29 \%)$ affirm that while some smaller sized green turtle $(<35 \mathrm{~cm}$ CCL) are sold, most are consumed by the fisher's family, especially if they are caught at the beginning of the "turtle season" (August to October), because it is considered as a symbol of prosperity from God.

We noted that the high demand for marine turtle products is not only driven by the needs of Indigenous local communities. In particular, nine of the wholesalers we interviewed said that they have sold, on at least one occasion in the past 5 years, turtle products to non-local and non-Indigenous people. In addition, three of the four buyers we interviewed were non-Indigenous people. From our interview data it appears that the products they purchased are obtained by fishers in the study area and are then transported to other places in the Zulia state, such as San Rafael del Moján, Maracaibo (capital city of Zulia state), La Cañada de Urdaneta, Sabaneta de Palmas (minor cities in Zulia state), and as far away as Mérida, Táchira and Lara States (Venezuelan Inland major cities) where the majority inhabitants are not Wayuú. However, although the majority of the inhabitants of these populated

Table 3 List of products and secondary products used commercially along the Southwestern Coast of the Gulf of Venezuela

\begin{tabular}{ll}
\hline Products and secondary - products & Price $^{*}$ \\
\hline Meat and guts (green/hawksbill/loggerhead) & US\$ 5 to 6 per kilo \\
Complete turtle (green turtle/hawksbill) & US\$ 163 to 210 \\
Marine turtle meal (restaurants) (all species) & US\$ 8 to 9 \\
Leatherback oil & US\$ 5 per Littre \\
Dried penis (green turtle/hawksbill) & US\$ 14 to 37 \\
Carapace (hawksbill) & US\$ 300 \\
Roosters spurs (hawksbill scutes) & US\$ 9 the pair \\
\hline
\end{tabular}

*prices calculated by 1 US dollar per 199 Venezuelan Bolivars (official Venezuelan rate in 2014 , called SIMADI) centres were non-Indigenous members, our respondents $(n=20)$ affirmed that in the urban centre of Maracaibo the sellers tend to be part of the extended family of the fishers or wholesaler/traders. In Maracaibo the main type of products sold were the turtle soup and turtle "empanadas" (similar to a meat pie), and they were sold both informally and at small restaurants (street stalls). We found this to occur in neighbourhoods where although traditionally Wayuú people lived, there is now a large proportion of mestizos (non-Indigenous people).

Thirty three of our respondents also provided information indicating that marine turtle products originating from Venezuela are being sent across the border into Colombia. The most common Colombian destinations are Riohacha and Maicao, which are cities lying adjacent to the Gulf of Venezuela and within the Colombian Guajira Peninsula (Fig. 1). However, there was less clarity around what species and products were being traded across the border as some respondents $(n=13)$ believed that the trade into Colombia comprised only of hawksbill turtle products (mainly its scutes) and the products were being sent to different cities such as: Valledupar, Santa Marta, Barranquilla, Cartagena de Indias, Rosario Islands (which are located outside of the Colombian portion of the Guajira Peninsula), or even into Panamá.

Of 35 interviewees, 21 Indigenous people believed there should be special exception to the marine turtle protection laws because of their traditional ancestry and the desire to maintain cultural-based use of the marine turtles. For example, one respondent claimed, “...Marine turtles are gift from Maleiwa, but the Alijünas do not understand that. This (the use of turtle) for us (Wayuu) should be legal, because is part of our culture. Look, I raised my family thanks to the marine turtles, and nowadays my grandsons are attending the primary school because I sell turtle meat to buy their books, uniforms, and everything,... but the army people does not understand that and tried to put me on jail..." (Table 2). This difference of opinion between Indigenous people and the legal situation creates a conflict between traditional customs and beliefs of Wayuú people and the agencies enforcing the national legal framework.

Between 2014 and 2017, as part of a separate study, we were able to re-visit all the trade centres and markets that we surveyed initially in 2002 (Table 1), and we were able to conduct market-based observations in each. Although, we found that the trade of products of green turtle, hawksbill, and leatherback turtle is still occurring in the area. We did not collect data on other social and economic aspects of the trade for these trips.

\section{Discussion}

Our results demonstrate that at least four species of marine turtle in Venezuela are subjected to use and 
trade, and their prices and value to the community are strongly influenced by culture, origin, species, product, quantity and demand and ethnicity from buyers. We found the most commonly traded species is the green turtle; however, the most expensive products were derived from the hawksbill turtle. The products varied in price from US\$5 (e.g. for 1 kilogram of turtle meat) up to US\$300 (for a carapace from an adult-sized hawksbill turtle - unmanufactured). Hawksbill turtle products were more expensive than products derived from the other species and this scenario is similar to those identified by Rueda-Almonacid et al. (1992) who found a clear difference between the prices of hawksbill, green, and loggerhead products when evaluating the trade of marine turtle products in the Colombian side of the Guajira Peninsula. It is possible that the species based differences could be related to the lower relative abundance to green turtles in our study area or more broadly in the Caribbean (Campbell 2014), or reflect the availability of preferred habitat types for the two species (Buitrago and Guada 2002; Parra 2002).

Our data demonstrate that despite use being illegal, the consumption of marine turtles is common and occurs without evidence of regulation or enforcement in the Guajira Peninsula. However, importantly, the Wayuú interviewees affirm that their people have an ancestral cultural connection with marine turtles and they used marine turtle products because they considered their use to be connected to an ancient cultural activity (Parra 2002; Rueda-Almonacid et al. 1992; Villate 2010). In the Wayuu's tradition and belief systems marine turtles represent a gift from God (Maleiwa) (Guerra Curvelo 2011), thus the use of them is seen as correct and regarded as culturally legal (Robles 2008; Rueda-Almonacid et al. 1992; Villate 2010). For instance, for the Wayuú people marine turtles represent the cattle of "Pulowi" (a deity). Several oral stories described how these animals were shared with the Wayuú people since ancient times to be consumed by Wayuú people (Chacín 2016), also some elders explained a story about a sacred place (called "Julirawanar" hill) where the turtles are treated and healed by "Pulowi" (Guerra Curvelo 2011). Hence, many of the products consumed have a significant traditional value (Villate 2010). Importantly, some Wayuú interviewees affirm that in some cases the turtle product is not sold, rather the products are exchanged and shared among or between families, especially if the product will be used as medicine. The most common marine turtle product exchanged between Wayuú families was the leatherback turtle oil, which the respondents told us was a traditional cure or prevention for respiratory problems such as asthma, especially in children.

Despite the existence of national and internationals laws that prohibit international trade of marine turtles (Guada and Sole 2000), our data and those of other researchers have found that Wayuú peoples follow their ancient laws and continue using marine turtles. However, there is now a commercial component to the trade (Robles 2008). Given the commercial nature of the trade, plus the existence of commercial marine turtle use in nearby country and cities (Amorocho 2003; Colombia 2002). It is necessary to improve our knowledge of how the trade may impact local and regional marine turtle populations (number of animals traded, species, and lack of enforcement). Understanding the scale of use in relation to the marine turtle population size and the stability of the region's marine turtle populations as well as the attitudes towards culturally appropriate management would be a useful future steps to aid marine turtle conservation in the southern Caribbean (Weiss 2011).

Thirty-two of the 35 interviewees stated that despite the cultural connections, it was the positive difference in monetary exchange rates when trading between the Colombian and Venezuelan currency that underpinned their part of the trade of marine turtles over the border. This international trade is possible because the Guajira Peninsula is located between Colombia and Venezuela, and traditional Wayuú territory occurs on both sides of the Peninsula's international border. Hence, the Wayuú people consider the entire peninsula as one ancient territory and not two nations (Chacín 2016; Perrin 1989; Rueda-Almonacid et al. 1992). Importantly, our data reveal that the Wayuú people do not recognise this type of trade as international and instead they believe it is a continuation of their ancient use and trade of resources within their traditional territory (all Guajira Peninsula) (Carrasquero and Finol 2010; Parra 2002). However, the social reality of the peninsula's depressed economy means that the products now tend to be used commercially. Indeed, some interviewees claim that is worth selling the products further afield such as into Colombia's populated centres of Maicao or Riohacha (Guajira Department) to achieve greater value due to the Bolivars-Colombian Pesos exchange rate. Similarly, we presume, based on our data, that it is the potentially high profit margins that drive fishers to sell hawksbill scutes (handcrafted or not) to Colombian localities, or even to other international destinations, such as Panama. Interestingly, this monetary exchange rate was the opposite in the 1980s and 1990s (Rueda-Almonacid et al. 1992) but it is not known whether the same or reverse patterns of use and trade existed.

We acknowledge that our data were collected over 15 years. During this timeframe communities and patterns of use could change. However, the information that we received on use type, tradition, and trade routes indicate these aspects have not changed. This is probably due to the nature of remote region of study area and the general lack of change in infrastructure. Plus the strong social background of the Wayuu communities settled in 
the Guajira Peninsula remains. Our findings indicate the trade of marine turtles remains a common issue in the study area. Indeed, during the last surveys between 2014 and 2017, we found marine turtle's products are still being sold in trade centres and markets. However, it was not possible to establish a comparison in price over time for the products, because of the high variability on the prices and incongruences among the interviewees' answers. This latter may be due to the lack of clarity about exchange rate between Venezuelan Bolivars and Colombian Pesos, and the annual inflation registered and reported by the Venezuelan Government during 2014 to 2017 (Banco Central de Venezuela 2014; 2016). Also, the high levels of ilicit activites that were detected Guajira Peninsula, such as smuggling essential goods (food and medicines) and fuel into Colombia, led the Government of Venezuela to declare an emergency state in the Peninsula and close the border with Colombia (IWGIA 2016).

We found that illegal trade of marine turtle products is an issue throughout the study region, especially among the inhabitants of the Venezuelan Guajira. However, the Venezuela Government is a signatory to several international treaties which prevent consumptive use and/or international trade of marine turtles, in particular, the Inter-American Convention for the Protection and Conservation of Sea Turtles and CITES (Campbell et al. 2002; Naro-Maciel 1998; Venezuela 1996a). Exemptions from national legislation for in-country use could be granted to a Government if they could demonstrate that the in country use is local, sustainable, and regulated. Thus, if the use of marine turtles by Wayuú people is to be continued a possible exemption and the detail of knowledge required should be investigated. It is however likely that the commercial component would need to be removed if an exception was granted. A similar provision occurs in Australia, where the Aboriginal and Torres Strait Islander People hold a legal right to continue cultural, non-commercial, use of marine turtles, and this right is managed under combinations of legislation and community-based management (Grayson et al. 2010).

Our study found the issue of commercial use of marine turtles is currently occurring in Venezuelan territory and the cultural component is a key aspect to it (Martínez 2011). The local NGO "Grupo de Trabajo en Tortugas Marinas del Golfo de Venezuela (GTTM-GV)" currently is carrying out a bilingual conservation-portfolio to address this situation in the area with the support of local stakeholders (Barrios-Garrido et al. 2012). However, it will be necessary to support the domestic and international relationships and discussions among all involved entities to design an effective and inter-institutional management plan that allow us to differentiate the traditional use and the illegal use and manage it along cultural and ecologically appropriate means.

\section{Conclusions}

The trade of marine turtle products is occurring in 12 populated centres of the South-eastern region of the Gulf of Venezuela, and some items may be found in national and international markets. The commercialised products vary in price according to the turtles size, species, and season of capture. Wayuú people use turtles for food, economic and cultural resources, and they believed they had legal exceptions to use marine turtle products based on their traditional beliefs. Further research is needed to identify and clarify what types of use may be considered illegal and legal. This will require opening a discussion between Government, Wayuú and other stakeholders.

\section{Appendix}

Table 4 Questionnaire (carried out in Spanish or Wayuúnaikii)

\begin{tabular}{ll}
\hline Topic & Questions \\
\hline General & 1. Gender \\
2. Age \\
3. Home town \\
4. What do you know about the presence of \\
marine turtles in the area? \\
5. Can you recognise the different species of marine \\
turtles present in the locality? (We used photos of \\
the species to validate the answers) \\
6. What do you know about the use of marine \\
turtle by the inhabitants of your locality? \\
1. Has trade of marine turtles has occurred in \\
your locality? \\
2. Have you heard about people trading marine \\
turtles in the area? \\
3. If yes, where does this trade occurs? \\
4. How many people are involved on this activity? \\
5. Can you please describe the routes used to \\
transport the products? \\
6. How did you get all this information? \\
7. Do you know the prices of the marine turtle \\
products (and secondary products) in the \\
local market? \\
1. Do you know what the cultural importance of \\
marine turtle for the Wayuú people is? Can you \\
please provide details?
\end{tabular}




\section{Acknowledgments}

We are grateful to the fishers of Castillete, Tapuri, Porshoure, Parashiou, Zapara Island, and San Bernardo Peninsula for their trust and assistance. We particularly thank Segundo Palmar (Paraguaipoa), Jhony Reverol (Kazuzain), Martín Oquendo (Castilletes), Francisco "Piñita" Rodríguez, Tibisay Rodríguez (Zapara Island), José Luis González, Abraham González (Porshoure), Lerminth Torres (NGO-Mangle), Helímenes Perozo (MPPAmb-Costa Oriental del Lago) and Neiro Flores (San Bernardo). We thank Chloe Nash (The University of Chicago-USA) for her help in improving the English of this manuscript. This research was authorised by Venezuela's Environmental Ministry (Ministerio del Poder Popular para el Ambiente), now the Ministry of Eco-Socialism and Water, via scientific hunting licenses 828, 886, and 1224. The 2014 surveys were covered under a James Cook University human ethics permit H5704. Héctor Barrios-Garrido's Ph.D. candidature at James Cook University is supported by an International Postgraduate Research Scholarship.

\section{Authors' contributions}

Conceptualisation: HBG, NER, JP, NW, MGM. Data collection: HBG, NER, DRC, JP, NW, MGMV. Formal analysis: HBG, MH. Supervision: MH. All authors read and approved the final manuscript. All authors read and approved the final manuscript.

\section{Competing interest}

The authors declare that they have no competing interests.

\section{Publisher's Note}

Springer Nature remains neutral with regard to jurisdictional claims in published maps and institutional affiliations.

\section{Author details \\ 'TropWATER - Centre for Tropical Water and Aquatic Ecosystem Research; College of Marine and Environmental Sciences, James Cook University, Townsville, Australia. ${ }^{2}$ Grupo de Trabajo en Tortugas Marinas del Golfo de Venezuela (GTTM-GV), Maracaibo, Venezuela. ${ }^{3}$ Laboratorio de Ecología General, Centro de Modelado Científico (CMC); Facultad Experimental de Ciencias, La Universidad del Zulia (LUZ), Maracaibo, Venezuela. ${ }^{4}$ Laboratorio de Ecología y Genética de Poblaciones, Centro de Ecología, Instituto Venezolano de Investigaciones Científicas (IVIC), Altos del Pipe, Venezuela.}

Received: 2 September 2015 Accepted: 24 March 2017

Published online: 23 May 2017

\section{References}

Acuña A, Gonzalez L, Guerrero M, Molero H, Pirela D, Rincon J, Sideregts L. Preliminary report on the status of the Sea Turtles on the Western Coast of the Golfo de Venezuela. Mayaguez: Zulia State. Paper presented at the Second Western Atlantic Turtle Symposium; 1989.

Amorocho D. Monitoring nesting loggerhead turtles (Caretta caretta) in the central caribbean coast of Colombia. Mar Turt Newsl. 2003;101:8-13.

Ankersen TT, Stocks G, Paniagua F, Grant S. Turtles without borders: the International and domestic law basis for the shared conservation, management, and use of sea turtles in Nicaragua, Costa Rica, and Panama. J Int'I Wildlife Pol. 2015;18(1):1-62. doi:10.1080/13880292.2014.957027.

Antczak A, Buitrago J, Mackowiack de Antczak MM, Guada H. Paper presented at the 59th Gulf and Caribbean Fisheries Institute. Belize City: Belize; 2007. A Contribution to the History of Marine Turtles Exploitation in Venezuela.

Balza-García R. El mal, jerarquía y función socio-simbólica en la cultura Wayüu. Un enfoque simbólico. Espacio Abierto Cuaderno Venezolano de Sociologia. 2010;19(1):93-115.

Banco Central de Venezuela, B. Resultados de la Economía durante el año 2014 Informe Anual. Caracas: Banco Central de Venezuela; 2014. Retrieved from http://www.bcv.org.ve/Upload/Comunicados/aviso301214.pdf.

Banco Central de Venezuela, B. Resultados del Índice Nacional de Precios al Consumidor, Producto Interno Bruto y Balanza de Pagos. Caracas: Banco Central de Venezuela, BCV; 2016. Retrieved from http://www.bcv.org.ve/ Upload/Comunicados/aviso150116.pdf.

Barrios-Garrido H. Análisis filogenético de la Tortuga Verde Chelonia mydas en el Golfo de Venezuela. (Licenciado en Biologia). Maracaibo: Universidad del Zulia; 2003
Barrios-Garrido H, Montiel-Villalobos MG. The sea turtle in magical-religious beliefs of the Wayuú indigenous people: Venezuela. NOAA Technical Memorandum NMFS SEFSC-536. 2006;(536):189.

Barrios-Garrido H, Montiel-Villalobos MG. Uses of the Sea Turtles by Wayuu people in the Gulf of Venezuela: "Native Oceans" of Venezuela, NOAA Technical Memorandum NMFS-SEFSC-602. 2010. p. 243-4

Barrios-Garrido H, Montiel-Villalobos MG. Strandings of Leatherback turtles (Dermochelys coriacea) along the western and southern coast of the Gulf of Venezuela. Herpetol Conserv Biol. 2016;11(1):244-52.

Barrios-Garrido H, Palmar J, Espinoza-Rodríguez N, Montiel L, Oquendo M, Moran L, Wildermann N. Sea Turtle conservation strategies in the Gulf of Venezuela: Investigation-Action multicultural efforts. NOAA Technical Memorandum NMFS SEFSC-631. 2012;(631):81.

Barrios-Garrido H, Wildermann N, Guada H, Buitrago J, Balladares C. Guaraguá, Lepidochelys olivacea. In: Rodriguez JP, Garcia-Rawlins A, Rojas-Suarez F, editors. Libro Rojo de la Fauna Venezolana. Caracas: Provita, Fundacion Empresas Polar; 2015.

Barrios-Garrido H, De Turris-Morales K, Delgado-Ortega G, Nash CM, EspinozaRodriguez N. Acoustic parameters of Guiana Dolphin (Sotalia quianensis) whistles in the Southern Gulf of Venezuela. Aquat Mamm. 2016;42(2):127-36. doi:10.1578/AM.42.2.2016.127.

Borrero Avellaneda WJ, Patiño EA, Guerra ML, Gouriyu WA. New evidence of nesting Dermochelys coriacea (Tortuga Achepa) at Iporoimao-Utareo Beaches, Guajira, Colombia. Mar Turt Newsl. 2013;137:13-4.

Bräutigam A, Eckert KL. Turning the Tide: Exploitation, Trade and Management of Marine Turtles in the Lesser Antilles, Central America, Colombia and Venezuela. Cambridge: TRAFFIC International; 2006.

Buitrago J, Guada H. LA TORTUGA CAREY (Eretmochelys imbricata) EN VENEZUELA. Interciencia. 2002;27:392-440.

Buitrago J, Guada HJ, Doyle E. Conservation science in developing countries: an inside perspective on the struggles in sea turtle research and conservation in Venezuela. Environmental Science and Policy. 2008;11(6):562-78. doi:10.1016/ j.envsci.2008.03.002

Buitrago J, Vera V, García-Cruz M, Montiel-Villalobos MG, Rodríguez-Clark KM, Peñaloza CL, Solé G. Tortuga Verde, Chelonia mydas. In: Rodriguez JP, GarciaRawlins A, Rojas-Suarez F, editors. Libro Rojo de la Fauna Venezolana. Caracas: Provita, Fundacion Empresas Polar; 2015a.

Buitrago J, Guada H, Rondón-Médicci M, Balladares C, De Los Llano V. Tortuga Carey, Eretmochelys imbricata. In: Rodriguez JP, Garcia-Rawlins A, Rojas-Suarez F, editors. Libro Rojo de la Fauna Venezolana. Caracas: Provita, Fundacion Empresas Polar; 2015b.

Butler JR, Tawake A, Skewes T, Tawake L, McGrath V. Integrating traditional ecological knowledge and fisheries management in the Torres Strait, Australia: the catalytic role of turtles and dugong as cultural keystone species. Ecol Soc. 2012;17:1-19. http://dx.doi.org/10.5751/ES-05165-170434.

Campbell CL. Conservation Status of Hawksbill Turtles in the Wider Caribbean Western Atlantic and Eastern Pacific Regions. Virginia: IAC Secretariat Pro Tempore; 2014

Campbell LM, Godfrey MH, Drif O. Community-based conservation via global legislation? Limitations of the inter-American convention for the protection and conservation of sea turtles. Journal of International Wildlife Law \& Policy. 2002;5(1-2):121-43. doi:10.1080/13880290209354002.

Carrasquero A, Finol JE. Mito, concepciones del cuerpo y yonna wayuu. Omnia. 2010;16(1):18-34

Castellano-Gil MA, Barrios-Garrido H. Cognitive structure of traditional fisherman and commercial fisherman Wayuu: an ethnographic study. 26th Book of Abstracts. 2006:(26):345-6.

Cerquera Gonzalez $\mathrm{CH}$. Clanes territoriales o clanes dispersos? algunas consideraciones generales sobre la estructura social Wayúu. Jangwa Pana. 2008;7(1):58-69.

Chacín H. Asombros del Pueblo Wayuu, vol. 2. Cabimas: UNERMB; 2016.

Colombia R d. Programa Nacional para la Conservación de las tortugas marinas y continentales en Colombia. 2002. Direcciones General de Ecosistemas. Ministerio del Medio Ambiente, Retrieved from http://www.widecast.org/ Resources/Docs/Programa_conservacion_de_tortugas_Colombia.pdf.

D'Lima C, Marsh H, Hamann M, Sinha A, Arthur R. Positive Interactions Between Irrawaddy Dolphins and Artisanal Fishers in the Chilika Lagoon of Eastern India are Driven by Ecology, Socioeconomics, and Culture. Ambio. 2014;43(5): 614-24. doi:10.1007/s13280-013-0440-4.

Fleming EH. Swimming Against the Tide: Recent Surveys of Exploitation, Trade, and Management of Marine Turtles In the Northern Caribbean. In: America TN, editor. TRAFFIC North America. 2001. p. 185. 
Frazier J. Marine turtles: the role of flagship species in interactions between people and the sea. Mast. 2005;4(1):5-38.

Frazier JG. The turtles' tale: flagships and instruments for marine research, education, and conservation. Smithson Contrib Mar Sci. 2009:38:241-6.

Grayson J, Hamann M, Marsh H, Ambar S. Options for managing the sustainable use of green turtles: Perceptions of Hammond Islanders in Torres Strait. Conserv Soc. 2010;8(1):73-83. doi:10.4103/0972-4923.62673.

Guada H, Sole G. WIDECAST Plan de Acción para la Recuperación de las Tortugas Marinas de Venezuela. In: Suarez A, editor. Informe Técnico del PAC (Vol. 39, pp. 112 + xiv). Kingston: UNEP Caribbean Environment Programme; 2000.

Guada H, Rondón-Médicci M, Barrios-Garrido H, Buitrago J, Balladares C, MontielVilalobos MG. Tortuga Cabezona, Caretta caretta. In: Rodriguez JP, GarciaRawlins A, Rojas-Suarez F, editors. Libro Rojo de la Fauna Venezolana. Provita: Caracas, Venezuela; 2015.

Guerra Curvelo W. El Universo simbolico de los pescadores Wayuu. Magdalena: Cultura. Universidad del Magdalena; 2011.

Hamann M, Godfrey M, Seminoff J, Arthur K, Barata P, Bjorndal K, Carreras C. Global research priorities for sea turtles: informing management and conservation in the 21st century. Endanger Species Res. 2010;11:245-69.

Humber F, Godley BJ, Broderick AC, Defeo O. So excellent a fishe: a global overview of legal marine turtle fisheries. Divers Distrib. 2014;1-12. doi:10.1111/ddi.12183

Ilo ILO. C169 - Indigenous and Tribal Peoples Convention. Convention concerning Indigenous and Tribal Peoples in Independent Countries. Geneva: ILO; 1989.

IWGIA. The Indigenous World 2016. Copenhagen: The International Work Group for Indigenous Affairs; 2016.

Lagueux CJ, Campbell CL, Strindberg S. Artisanal green turtle, Chelonia mydas, Fishery of Caribbean Nicaragua: I. catch rates and trends, 1991-2011. PLoS One. 2014;9(4):e94667. doi:10.1371/journal.pone.0094667.

Macías MA, Garzón JC. Revisión bibliográfica analítica sobre los elementos culturales de la familia de los pueblos amerindios Kogi y Wayúu. Psicología desde el Caribe. 2005;16:128-47.

Mancini A, Koch V. Sea turtle consumption and black market trade in Baja California Sur, Mexico. Endanger Species Res. 2009;7:1-10. doi:10.3354/esr00165.

Martínez AM. Understanding the Constraints of Rural Education for the Conservation of Sea Turtles in La Guajira, Colombia. Literacy Information and Computer Education Journal. 2011;2(4):513-20.

Medina E, Barboza F. Mangroves of the Maracaibo lake system: physiographic and ecological characterization. Ecotropicos. 2003;16(2):75-82.

Montiel-Villalobos MG. Efecto de la extracción artesanal de la tortuga verde, Chelonia mydas, en el Golfo de Venezuela: Conexiones entre hábitats de alimentación y áreas de anidación reveladas por ADN mitocondrial, Doctor en Ciencias, mencion Ecologia. Altos del Pipe, Estado Miranda: Instituto Venezolano de Investigaciones Cientificas (IVIC); 2012.

Morán L, Severeyn H, Barrios-Garrido H. Moluscos bivalvos perforadores de rocas coralinas submareales de la alta Guajira, Golfo de Venezuela. Interciencia. 2014;39(2):136-9.

Nada M, Casale P. Sea turtle bycatch and consumption in Egypt threatens Mediterranean turtle populations. ORYX. 2011;45(01):143-9. doi:10.1017/ s0030605310001286.

Naro-Maciel E. The Inter-American convention for the protection and conservation of sea turtles: An historical overview. Journal of International Wildlife Law and Policy. 1998;1(1):169-78.

Olijdam E. Exploitation of sea turtles in the early Dilmun period (c. 2100-1900 BC). Proceedings of the Seminar for Arabian Studies. 2001;31:195-202.

Parra L. Diagnóstico de la situación actual de las poblaciones de tortugas marinas en la Costa Occidental del Golfo de Venezuela, estado Zulia. (Licenciado en Biologia). Maracaibo: Universidad del Zulia; 2002.

Paz Reverol CL, Leal Jerez M, Alarcón Puentes J, Valbuena Chirinos C, García Gavidia N, Flores Díaz D. Ser curador wayúu en la globalización y no morir en el intento. Index de Enfermería. 2010;19(2-3):88-92.

Perrin M. Creaciones miticas y representacion del mundo: el hombre blanco en la simbologia Guajiro. Antropologica. 1989;72(1989):41-60.

Rees A, Alfaro-Shigueto J, Barata P, Bjorndal K, Bolten A, Bourjea J, Godley BJ. Are we working towards global research priorities for management and conservation of sea turtles? Endanger Species Res. 2016;31:337-82. doi:10.3354/esr00801.

Riaño-Alcalá P. Emplaced witnessing: commemorative practices among the Wayuu in the Upper Guajira, Memory Studies. 2014. 1750698014563970.

Richardson PB, Broderick AC, Campbell LM, Godley BJ, Ranger S. Marine turtle fisheries in the UK overseas territories of the Caribbean: Domestic legislation and the requirements of multilateral agreements. Journal of International Wildlife Law and Policy. 2006;9(3):223-46. doi:10.1080/13880290600764935.

Roberts JD, Hamann M. Testing a recipe for effective recovery plan design: a marine turtle case study. Endanger Species Res. 2016;31:147-61. doi:10.3354/esr00755.

Robles DA. Beyond Assimilation Vs. Cultural Resistance: Wayuu Market Appropriation in Riohacha, La Guajira, Colombia, Master of Arts. Department of Anthropology and the Faculty of the Graduate School of the University of Kansas. Kansas, 2008

Roe Hulse KJ. Indigenous Knowledge of Marine Ecosystems: Consumption, commercialization and Management in the Miskito Community of Sandy Bay and the Rama Community of Punta Aguila, Caribbean Coast of Nicaragua, Master of Science in International Fisheries Management. Norway: University of Tromsø; 2005.

Rojas-Cañizales D. Evaluación de la extracción de tortugas marinas mediante la pesca artesanal en Kazuzain, Guajira Venezolana, Licenciado en Biologia. Maracaibo: Universidad del Zulia; 2015.

Rondón-Médicci M, Guada H, Buitrago J, Balladares C. Cardon, Dermochelys coriacea. In: Rodriguez JP, Garcia-Rawlins A, Rojas-Suarez F, editors. Libro Rojo de la Fauna Venezolana. Caracas: Provita, Fundacion Empresas Polar; 2015.

Rueda-Almonacid JV, Mayorga JE, Ulloa G. In: I. N. d. I. R. N. R. y. d. A.-. Inderena, editor. Contribucion al conocimiento de las Tortugas Marinas de Colombia. Bogota: Biblioteca Andres Posada Arango; 1992. p. 133-53.

Sideregts L, Guerrero ME, Acuña A, Molero H, Pirela D, González L, Rincón JE. Informe preliminar sobre la situación actual de las tortugas marinas en el Golfo de Venezuela, Estado Zulia. Maracaibo: Museo de Biologia de La Universidad del Zulia (MBLUZ). Facultad Experimental de Ciencias. LUZ; 1987. p. 14.

Soré Y, Barboza P, D' Apollo M, Sanchez D, Barrios-Garrido H, Montiel-Villalobos MG. Sea Turtle: Wayuu treasure. 26th Book of Abstracts. 2006;(26):359-60.

Stringell TB, Calosso MC, Claydon JAB, Clerveaux W, Godley BJ, Lockhart KJ, Broderick AC. Marine turtle harvest in a mixed small-scale fishery: Evidence for revised management measures. Ocean \& Coastal Management. 2013;82: 34-42. doi:10.1016/j.ocecoaman.2013.05.004.

Tambiah C. Interviews and Market surveys. In: Eckert KL, Bjorndal KA, AbreuGrobois FA, Donnelly M, editors. Research and Management Techniques for the Conservation of Sea Turtles. Blanchard: IUCN/SSC Marine Turtle Specialist Group Publication No. 4; 1999. p. 156-61.

Venezuela R d. Convención Interamericana para la Protección y Conservación de las Tortugas Marinas. Venezuela: Caracas; 1996a. Retrieved from http://www. iacseaturtle.org/docs/Texto-CIT-ESP.pdf.

Venezuela R d. Gaceta Oficial No. 36.059. Lista de Animales Vedados para la Caza. Decreto No. 1485. 1996b.

Venezuela R d. Gaceta Oficial No. 296.504. Lista de Especies en Peligro de Extinción. Decreto No. 1486. 1996c.

Venezuela RB. Ley Organica de Pueblos y Comunidades Indigenas. Caracas: Ministerio del Poder Popular para los Pueblos Indigenas. Asamblea Nacional; 2005.

Venezuela RB. Ley de Pesca y Acuicultura. Caracas: Tribunal Supremo de Justicia; 2014. Retrieved from http://extwprlegs1.fao.org/docs/pdf/ ven 147977.pdf.

Vernet PD, Gómez ÁJ. Red de aviso oportuno: estrategia para la conservación de las tortugas marinas en la Isla de Margarita, Venezuela. Memoria de la Fundación La Salle de Ciencias Naturales. 2007;167:101-10.

Villate R. The ecology and commerce of sea turtles at the Colombian Guajira. Saarbrucken: Lambert Academic Publishing; 2010.

Wallace BP, Bjorndal KA, Bourjea J, Bowen BW, Briseño Dueñas R, Casale P, Mast RB. Global conservation priorities for marine turtles. PLoS One. 2011;6(9), e24510. doi:10.1371/journal.pone.0024510.

Weiss K. Towards social-ecological resilience in natural resource governance: issues of power, diversity and scale, Doctor in Philosophy. Townsville: James Cook University; 2011.

Weiss K, Hamann M, Marsh H. Bridging knowledges: understanding and applying indigenous and western scientific knowledge for marine wildlife management. Soc Nat Resour. 2013;26(3):285-302. doi:10.1080/08941920.2012.690065. 